\title{
DEVELOPMENT OF THE 'AUSTRALASIAN' WOODLAND AT LOGAN BOTANIC GARDEN
}

\author{
Barry Unwin ${ }^{1}$
}

Logan Botanic Garden, one of the Regional Gardens of the Royal Botanic Garden Edinburgh, has a very mild climate when its northerly latitude is considered. This allows the cultivation of a remarkable range of what would normally be described as exotic, semi hardy plants to be grown. This paper describes the species selection, design and development of a newly refurbished part of the garden, the 'Australasian' woodland.

\section{INTRODUCTION}

Situated in the extreme south west corner of Scotland in the Rhins of Galloway Logan Botanic Garden (one of the three Regional Gardens of the Royal Botanic Garden Edinburgh) benefits from the warming influence of the Gulf Stream and winters that are considerably milder than other parts of the country. This allows a range of rare and exotic species from the Southern Hemisphere, and other temperate regions of the world, to flourish out of doors.

\section{EARLY STAGES}

In the mid 1970's the only shelter in the south woodland (Plate 1) was provided by the many sycamore trees which had previously been encouraged to grow and provide protection from the salt laden prevailing south westerly gales. Any attempts to establish more interesting material generally failed as any planting pockets which were prepared soon became choked with 'couch grass', Agropyron repens (Graminae). Following discussions of the development of the south woodland in 1977 large areas of grass were sprayed off and large numbers of Pittosporum tenuifolium (Pittosporaceae) were planted. The idea was that, when mature, these plants would provide shelter and act as "nurse plants' for more interesting species from the Southern Hemisphere. These grew quite quickly and within ten years these plants had become well established. Thereafter it was not too long before they started to offer some protection from the prevailing south westerly winds. During the winters of 1987-8 \&1988-99 most of the sycamores were removed and their roots dug out. This was the first stage of development into a more natural 'Australasian' woodland setting. There were already a number of tree ferns growing here. Dicksonia antarctica (Dicksoniaceae) from Australia, and D. fibrosa, from New Zealand were benefiting from the protection afforded by the canopy of established Eucalyptus species that had been planted several years earlier.

Initially only a few of the pittosporums were removed to allow space for planting small tree ferns which had self seeded from the more mature plants in the walled garden.

'Barry Unwin is Curator of Logan Botanic Garden. Address: Port Logan, Stranraer, Wigtownshire DG9 9ND.

Email b.unwin@rbge.org.uk 
Unfortunately about 50 of the first 'crop' were killed during the winter of 1995/96, when temperatures in the Garden fell to $-10.4^{\circ} \mathrm{C}$. This was still relatively mild, compared to other parts of Scotland where temperatures as low as $-24^{\circ} \mathrm{C}$ were recorded, but it was a sharp reminder of what can happen, even down here in the 'Banana Belt'. It was decided then that young plants would be wrapped in future winters (Plate 2). Although this was a setback, it wasn't too major as another batch of young plants had survived in the shelter of a cool greenhouse.

Not disheartened by events of the previous winter, work continued and more of the pittosporums were removed to allow the transplantation and spacing out of some of the tree ferns which had survived. Most of these were up to about 20 years old and had spent the first few years of their life under glass. They had initially been planted quite close together in groups so as to help shelter each other. Several other specimens of Dicksonia antarctica and D. fibrosa were lifted from other parts of the garden and added to the existing plantings.

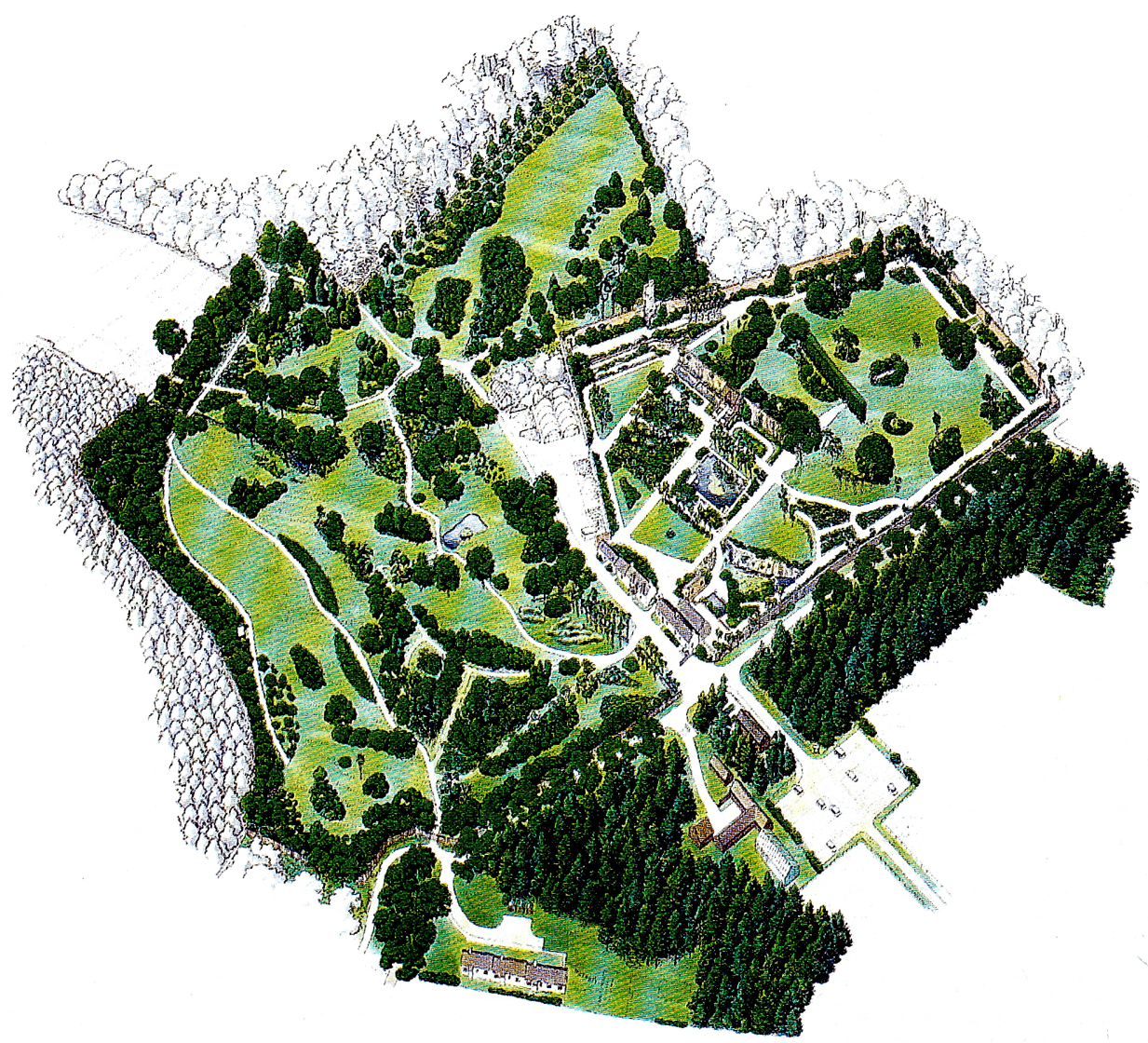

Plate 1. Plan of Logan Botanic garden. The south woodland is the wooded area towards the bottom of the plan above the diagonal path running from the bottom left upwards to the right. 


\section{TREE FERN CULTIVATION}

Transplanting mature tree ferns is hard work but is fairly straight forward. It is possible to cut them off above soil level and plant the stump as it is. Nearly all the material imported from Australia and New Zealand arrives as sections of dormant trunks. The retail growers then pot up these stumps and water them thoroughly to encourage the growth of new fronds before selling them. Although most of these plants are harvested under licence from areas where logging is to be carried out there are some which are illegally harvested and do not have certificates of authenticity.

When visiting some of the National Parks in Tasmania in 1996 I noticed that tree fern trunks had been used to make steps! At that time, licences were available to clear tree fern trunks from areas prior to logging and for this privilege the princely sum of $50 \mathrm{p}$ per metre was charged. Somewhere in the chain people are making a lot of money from importing these plants to Britain.

There is quite a lot of confusion regarding the requirements of these plants. This is illustrated by the claims of one well established, and reputable, nursery in their information sheet on tree ferns.

'They are 'top feeders', catching all the moisture and nutrients they require in their large canopy. There is no moisture or nutrient exchange through the trunk, making the type of soil irrelevant, they will be equally happy in brick rubble as in the finest compost.'

I totally disagree with this statement and from many years experience I have always found that the richer the compost the better the growth. For this reason at Logan we always go to great lengths to prepare a good planting pit before moving any tree ferns. Usually the plants are lifted carefully with as big a root ball as possible. Very rarely do we cut the top off and plant the trunk. A large hole is dug and plenty of organic matter and bone meal is incorporated into the soil before planting. In the past we always used peat for this purpose, more recently composted bark or our own garden compost is used. The plants are then watered in and kept watered throughout any dry weather.

Although growing tree ferns has now become very fashionable, they have been growing here at Logan Botanic Garden for almost 100 years. It is not known exactly when the first ones were planted, or indeed how large they were at the time of planting. However, it is well documented that in the mid 1920s the tallest ones in the garden were about $2.3 \mathrm{~m}$ high. Some 80 years or so later these plants are now almost double that height. Even in this favourable climate they only grow about $25 \mathrm{~cm}$ each year.

\section{SPECIES SELECTION}

The next phase of the development was to acquire some of the more unusual and tender species of tree fern and their allies. These provide for greater interest and add to the fascinating range of plants already growing in the area. The most recently planted species include Cyathea dealbata (Dicksoniaceae), which naturally grows in the sub 
canopy of drier forests and open scrub throughout New Zealand. It has the most amazing dark green fronds with a silver underside. Cyathea dealbata has been adopted as one of New Zealand's national emblems and strikes fear into the opposition when they see it on the shirts of the All Black rugby players! Cyathea australis, a native of Tasmania and eastern Australia, can grow up to $20 \mathrm{~m}$ in the wild. It is frequently subjected to snow in its natural habitat and has proved quite hardy to date. Dicksonia squarrosa is one of the most common Tree Ferns in New Zealand and the trunks of this plant are often used as fencing material and for other landscape features. It will grow quite well in shade or full sun, although specimens look better if they are given some protection. Young plants of this species have been growing very well for the past few years here in the garden. Interestingly, this particular species has the ability to shoot from near the base if the crown is frosted and killed. Culcita macrocarpa (Dicksoniaceae), also thrives at Logan and has survived now for several winters. It has a prostrate creeping trunk and occurs naturally in Spain, Portugal, Madeira, the Azores and Tenerife.

More recent developments have seen 'inappropriate species' removed to make way for more interesting plant material. A hedge of Griselinia littoralis (Griseliniaceae) was planted to provide additional shelter and many species of known wild origin were introduced. A number of Cyathea dealbata, and the prostrate form of Dicksonia lanata were transplanted to allow them more space to develop had it hitherto been possible. $D$. lanata is found in montane and sub-montane areas of central and southern New Zealand. However, there is also a form which produces a trunk up to $2 \mathrm{~m}$ high. It grows as an understory plant in lowland forests of Agathis australis (Araucariaceae) in the northern part of New Zealand, and is generally more frost sensitive.

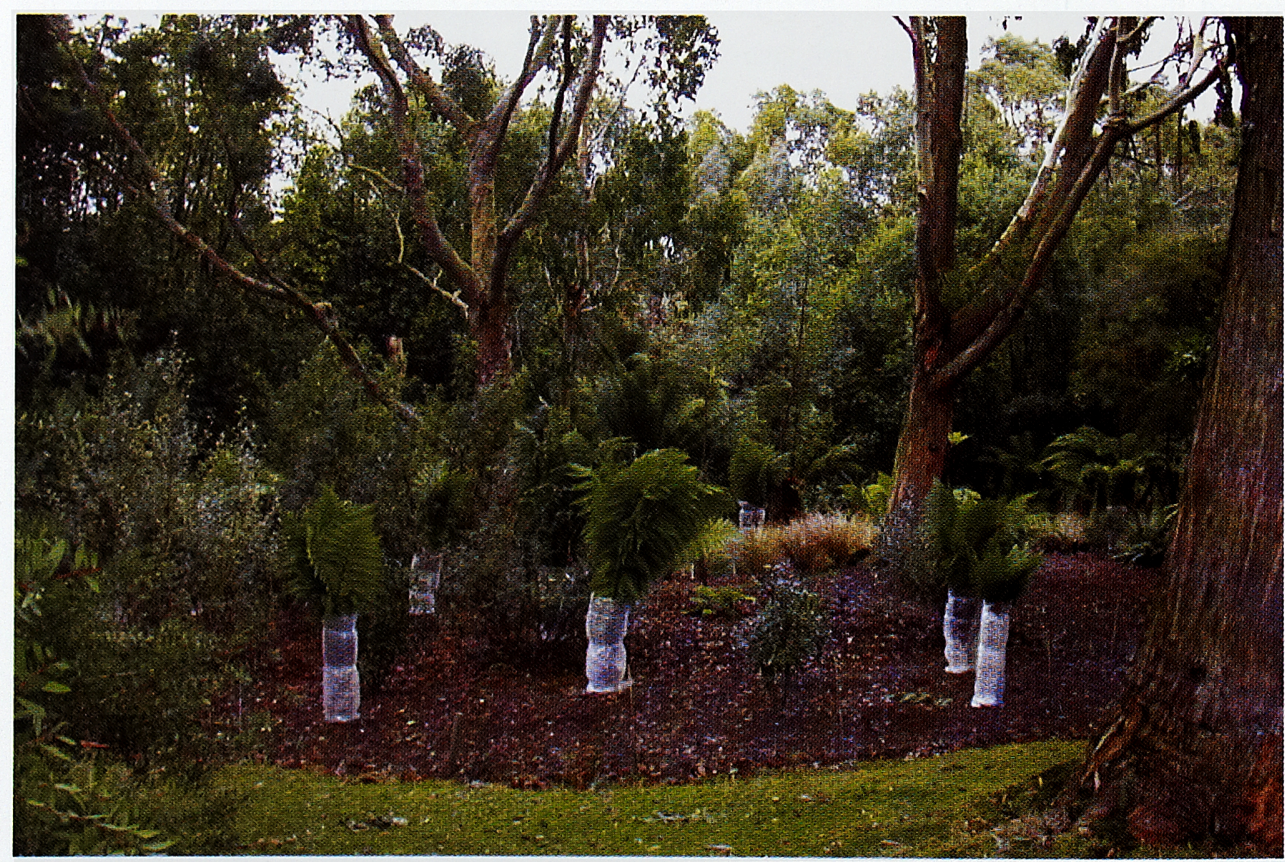

Plate 2. Young Tree Ferns wrapped up for winter 


\section{PLANTING THE WOODLAND}

During the closed season of 2002-3 (November-March), a large area was cleared in the west woodland. Several big sycamores, a very old beech tree, Rhododendron ponticum and other scrub material were removed. During these operations an old retaining wall was unearthed which also had to be excavated and removed. Once the groundwork was complete the first batch of over 50 Dicksonia antarctica was planted. Many of these were up to 15 years old and had been raised from natural regeneration from the older specimens elsewhere in the garden. A number of Eucalyptus (Myrtaceae) species have now been positioned throughout the site to provide shade and shelter. These include E. coccifera, $E$. pulchella and $E$. delegatensis subsp. tasmanensis, all of which were collected as seed in Tasmania. A number of the evergreen Drimys lanceolata (Winteraceae) have also been included. Once completed, this will be a unique feature, and nowhere else in Scotland will these magnificent plants be seen growing so well, and in such profusion, outside.

A large specimen of Thyrsopteris elegans, a monotypic fern native to the island of Juan Fernandez, which lies off the west coast of Chile, was planted out during 2003 (see Ensoll and Matthews, 2004). It remained evergreen during the winter months and is now producing healthy young fronds. This is probably the only example of this plant growing out of doors anywhere in Britain.

In addition to all the ferns in the South Woodland there have been many different species of trees, shrubs, grasses and other herbaceous material included. Wherever possible natural plant associations have been created so that plants can be seen growing as they would in their natural habitat. Clematis terniflora (syn. C. paniculata) (Ranunculaceae) is probably the most beautiful and best known of the New Zealand species and was introduced to Britain in 1840. It has large single white fragrant flowers and can be seen scrambling through some of the remaining Pittosporum tenuifolium. Clematis aristata (Plate 3), produces small star shaped flowers during early summer and these too are very fragrant. These plants, which can also be seen scrambling through some of the Australian Leptospermum species were collected as seed in Tasmania in 1996. Billardiera longifolia, from Australia, is a member of the Pittosporaceae and is covered with the most amazing purple coloured fruits during late summer. It grows well through the canopy of other Australian species and up the trunks of Dicksonia antarctica.

Two contrasting species of fuchsia from New Zealand can also be seen here. The tree-like $F$. excorticata (Onagraceae) will reach heights of over $6 \mathrm{~m}$ and has light brown exfoliating bark, which used to be dried and used as a form of tobacco by early settlers. It produces bizarre shiny green and purple flowers with blue pollen from early January through to the summer months. This plant was discovered by Banks and Solander during their first voyage on the Endeavour, and is probably one of the biggest fuchsias to be found anywhere in the world. By contrast, Fuchsia procumbens is only a few centimetres high and holds its pale orange, purple and green flowers erect throughout the summer months. These are followed by large red fruits in autumn.

The biggest trees in this area are some of the many different Eucalyptus species growing here at Logan. Fine specimens of Nothofagus menziesii (Fagaceae) and $N$. cunninghamii are also growing here, both are over $10 \mathrm{~m}$ high. The genus Olearia 


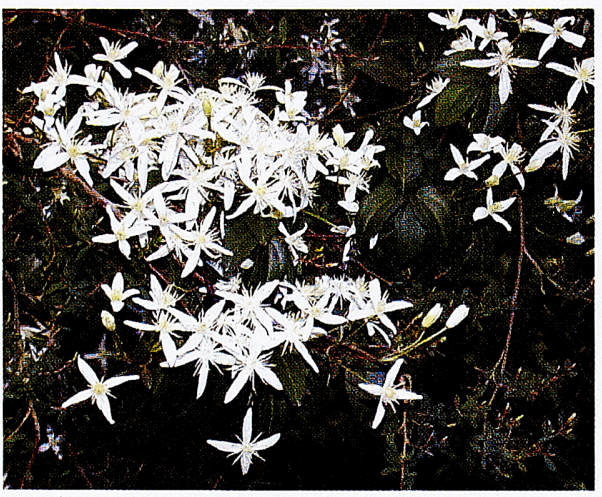

Plate 3. Clematis aristata

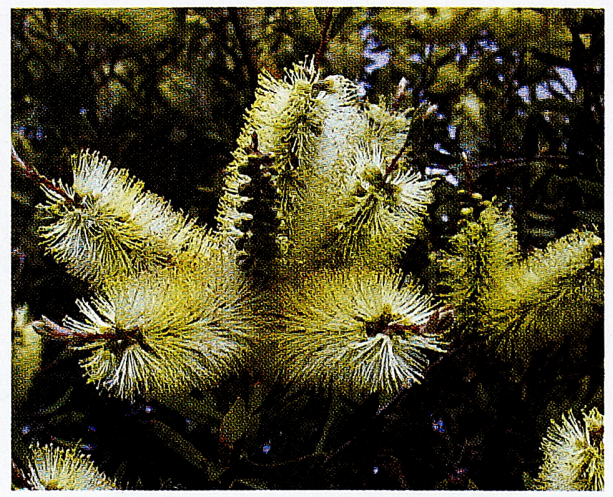

Plate 4. Callistemon viridiflora is also planted in the Australasian woodland

is also very well represented and includes the rare and endangered $O$. semidentata (Compositae) and O. chathamica, from the Chatham Islands and $O$. frostii from Australia. As well as Pittosporum tenuifolium several other pittosporums are here and these include $P$. dallii and . patulum, both of which are considered rare in their native New Zealand. Apart from the many different ferns, there is also a selection of non woody material, particularly different species of Chionochloa, Astelia, Libertia and Myosotidium hortensia (Boraginaceae). Other species to be found in this new 'Australasian' woodland are listed in Appendix 1.

\section{REFERENCE}

ENSOLL, A. \& MATTHEWS, K. (2004). Cultivation of Thyropteris elegans. Sibbaldia: An occasional series of horticultural notes from the RBGE 2, 27-31. 
APPENDIX I

\begin{tabular}{|c|c|c|}
\hline Blechnaceae & $\underline{\text { Davalliaceae }}$ & Dennstaedtiaceae \\
\hline $\begin{array}{c}\text { Blechnum australis } \\
\text { B. chilense } \\
\text { B. fluviatile } \\
\text { B. novae-zelandica } \\
\text { B. nudum } \\
\text { Doodia media } \\
\text { Woodwardia radicans } \\
\text { W. unigemmata }\end{array}$ & Rumohra adiantiformis & $\begin{array}{c}\text { Histiopteris incisa } \\
\text { Paesia scaberula } \\
\text { Sphenomeris chinensis }\end{array}$ \\
\hline Dryopteridaceae & Polypodiaceae & Woodsiaceae \\
\hline $\begin{array}{c}\text { Cyrtomium fortunei } \\
\text { Dryopteris fraser-jenkinsi } \\
\text { Polysticum alticola } \\
\text { P. lentum } \\
\text { P. proliferum } \\
\text { P. richardii } \\
\text { P. vestitum }\end{array}$ & Polypodium glycyrrhiza & Athyrium puncticaule \\
\hline Cupressaceae & Podocarpaceae & Taxodiaceae \\
\hline $\begin{array}{c}\text { Callitris rhomboidea } \\
\text { Libocedrus bidwillii } \\
\text { L. plumosa }\end{array}$ & $\begin{array}{c}\text { Dacrycarpus dacrydiodes } \\
\text { Largarostrobus franklinii } \\
\text { Podocarpus nivalis } \\
\text { P. totara }\end{array}$ & Taiwania cryptomeriodes \\
\hline Restionaceae & Araliaceae & Leguminosae \\
\hline Restio tetraphyllus & $\begin{array}{c}\text { Pseudopanax arborea } \\
\text { P. crassifolium } \\
\text { P. ferox }\end{array}$ & $\begin{array}{l}\text { Acacia dealbata } \\
\text { Carmichaelia aligera } \\
\text { Sophora prostrata } \\
\text { S. tetraptera }\end{array}$ \\
\hline Compositae & Graminae & Casuarinaceae \\
\hline $\begin{array}{c}\text { Brachyglottis monroi } \\
\text { B.huntii } \\
\text { Olearia arborescens } \\
\text { O. argophylla } \\
\text { O. avicennifolia } \\
\text { O. furfuraceae } \\
\text { O. ilicifolia } \\
\text { O. paniculata } \\
\text { O. odorata } \\
\text { O. solandrii } \\
\text { O. virgata }\end{array}$ & $\begin{array}{c}\text { Chionochloa conspicua } \\
\text { C. flavicans } \\
\text { C. rigida }\end{array}$ & Allocasuarina duncanii \\
\hline Asteliaceae & Rubiaceae & Iridaceae \\
\hline $\begin{array}{c}\text { Astelia chathamica } \\
\text { A. fragrans } \\
\text { A. grandis }\end{array}$ & $\begin{array}{l}\text { Coprosma alpina } \\
\text { C. lucida }\end{array}$ & $\begin{array}{c}\text { Diplarrhena latifolia } \\
\text { D. moraea } \\
\text { Libertia peregrinans lanceolata } \\
\text { L. ixioides }\end{array}$ \\
\hline Agavaceae & Winteraceae & Myrtaceae \\
\hline $\begin{array}{l}\text { Cordyline banksii } \\
\text { C. indivisa }\end{array}$ & $\begin{array}{c}\text { Drimys lanceolata } \\
\text { Pseudowintera colorata }\end{array}$ & $\begin{array}{c}\text { Callistemon linearris } \\
\text { C. pallidus } \\
\text { C. viridiflora } \\
\text { Leptospermum continentale } \\
\text { L. incanum } \\
\text { L. lanigerum } \\
\text { L. nitidum } \\
\text { L. scoparium } \\
\text { Lophomyrtus obcordatus } \\
\text { Melaleuca lanceolata } \\
\text { M. squamea } \\
\text { M. squarrosa } \\
\text { Meterosideros umbellata }\end{array}$ \\
\hline Phormiaceae & Pittosporaceae & Moniminiaceae \\
\hline $\begin{array}{l}\text { Dianella intermedia } \\
\text { D. tasmanica }\end{array}$ & $\begin{array}{c}\text { Pittosporum bicolor } \\
\text { P. crassifolium } \\
\text { P. eugenioides }\end{array}$ & Atherosperma moschatum \\
\hline Escalloniaceae & Epacridaceae & Eucryphiaceae \\
\hline Carpodetus serratus & Richea scoparia & Eucryphia moorei \\
\hline \multicolumn{3}{|l|}{ Myrsinaceae } \\
\hline Myrsine divaricata & & \\
\hline
\end{tabular}


